


\section{DISCLAIMER}

This report was prepared as an account of work sponsored by an agency of the United States Government. Neither the United States Government nor any agency Thereof, nor any of their employees, makes any warranty, express or implied, or assumes any legal liability or responsibility for the accuracy, completeness, or usefulness of any information, apparatus, product, or process disclosed, or represents that its use would not infringe privately owned rights. Reference herein to any specific commercial product, process, or service by trade name, trademark, manufacturer, or otherwise does not necessarily constitute or imply its endorsement, recommendation, or favoring by the United States Government or any agency thereof. The views and opinions of authors expressed herein do not necessarily state or reflect those of the United States Government or any agency thereof. 


\section{DISCLAIMER}

Portions of this document may be illegible in electronic image products. Images are produced from the best available original document. 


\section{NOTICE}

This report was prepared as an account of work sponsored by the United States Government. Neither the United States nor the United States Energy Research and Development Administration, nor any of their employees, nor any of their contractors, subcontractors, or their employees, makes any warranty, express or implied, or assumes any legal liability or responsibility for the accuracy, com-

pleteness or usefulness of any information, apparatus, product or process disclosed or represents that its use would not infringe privately owned rights. 
MLM-24I8

Distribution Category: UC-4

\title{
Investigation of Moisture in Titanium Metal Powder by Pulsed NMR
}

\author{
Albert Attalla, Robert C. Bowman, Jr., Bartlett D. Craft, \\ Calvin M. Love and Ralph L. Yauger
}

Issued: May 13, 1977

PRINTED IN THE UNITED STATES OF AMERICA

Available from

Notional Technical Information Service

U.S. Department of Commerce

5285 Part Royal Rosd

Springfield, Virginia 22161

Price: Printed Copy 53.50; Microtiche $\$ 3.00$

\section{MONSANTO RESEARCH CORPORATION}

A Subsidiary of Monsanto Company

\section{MOUND IABORATORY}

Miamisburg, Ohio

45342

operated for

\section{UNITED STATES ENERGY RESEARCH AND DEVELOPMENT ADMINISTRATION}

U. S. Government Contract No. EY-76-C-04-0053

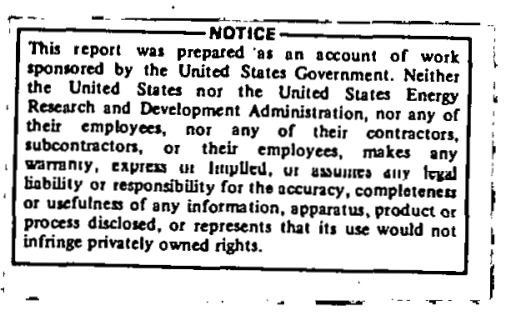




\begin{abstract}
A sample of titanium metal powder QC 1779 was subjected to five different treatments of drying and moisture exposure to estimate the effectiveness of normal drying and handling procedures used in the pyrotechnics processing. The treatments were drying in air, drying in two different vacuum furnaces, exposure to normal humidity and exposure to 1008 humidity. Statistical evaluation of the NMR results indicate that there is a significant difference between the moisture content of each treatment. Although the combined effects of temperature, pressure, humidity, and treatment time were not studied in a designed manner to determine their significance on the effectiveness of the drying techniques and moisture uptake by sample QC 1779, the experimental evidence does indicate that all four variables do affect the results of the treatments.
\end{abstract}

\section{INTRODUCTION}

A long-range study is under way to evaluate the effect of moisture on the firing performance of titanium hydride/potassium perchlorate pyrotechnics. It is believed that during long-term storage (20 yr) the effect of low-grade chemical reaction of moisture in the pyrotechnic may cause detrimental effects on the function of the pyrotechnic device. Since the greatest source of moisture in pyrotechnic materials is the atmosphere, knowledge of the moisture content of pyrotechnic materials subjected to various treatments of drying and atmospheric moisture exposure would be valuable in evaluating the behavior of pyrotechnic mixtures.

\section{EXPERIMENTAL}

The purpose of this NMR stuay was the evaluation of several drying techniques and of several treatments for the desorption and adsorption of water by titanium metal powder. From each of the five treatments, three aliquots of approximately $0.7 \mathrm{~g}$ were sealed in $9 \mathrm{~mm} 0 . \mathrm{d}$. pyrex glass tubes for NMR study. Tubes from treatments $T_{3}$, IV, and $V$ were sealed in air; the others were sealed under vacuum.

Six $1 / 2-\mathrm{mI} \mathrm{H}_{2} \mathrm{O}$ standard samples were used to calibrate the response of the NMR spectrometer to hydrogen. The concentration

TREATMENTS

I. Damp, softly caked, titanium metal powder identified as sample QC 1779 was allowed to dry at room temperature in the laboratory over the weekend.

II. $8.36 \mathrm{~g}$ of the air-dried material was subjected to a vacuum of $10^{-5}$ torr at $195^{\circ} \mathrm{C}$ for $88 \mathrm{hr}$.

III. The remainder of the air-dried material, from treatment $I$, was heated for $24 \mathrm{hr}$ in a vacuum furnace at $105^{\circ} \mathrm{C}$ and $50 \mu \mathrm{m}$ pressure.

IV. The remainder of the material from the third treatment was exposed to air for $1 \mathrm{hr}$.

V. The remainder of the material from the fourth treatment was exposed to 1008 humidity in a sealed desiccator for $45 \mathrm{hr}$ at room temperature. 
of the standards were $11.0,9.0,7.2,5.0$, 3.0 , and 1.0 in units of $10^{20}$ nuclear spins per $1 / 2 \mathrm{ml}$. The weakest water standard was used to correct for hydrogen background. The NMR proton signal from the background sample was subtracted electronically from that of the others. The NMR standards data were plotted as a function of corrected concentration to obtain a straight-line function. The titanium metal powder samples were run under the same conditions as the standards. The free induction decay (FID) amplitude at zero time was measured from the straight-line extrapolation of the FID signal to zero time (Figure 1 ). An empty glass tube was used to correct for the hydrogen background in the titanium samples. The proton spin-count of each titanium sample was determined from a linear regression analysis of the standards' data. The hydrogen content of each sample was calculated in terms of wt $\%$ hydrogen and wt \% water for data interpretation.

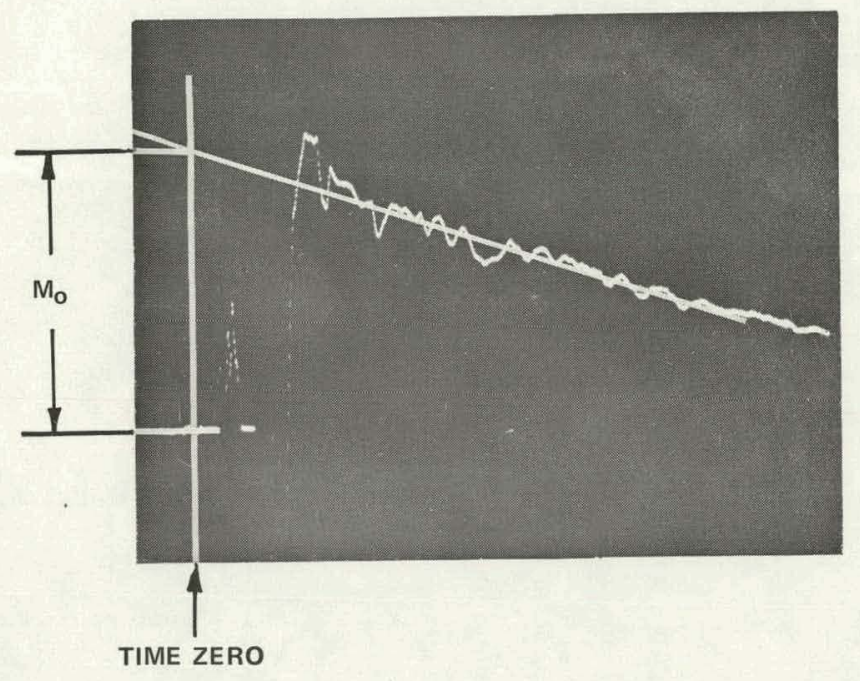

FIGURE 1 - Pulsed NMR proton free induction decay signal extrapolated to zero time in titanium metal powder sample Q 1779 .

\section{STATISTIC EVALUATION}

Table 1 lists the results of the NMR hydrogen determinations in weight percent water and hydrogen. The latter results are added for later comparison with total hydrogen determinations by other methods. Statistical evaluation of these results was performed only on the weight percent water data, since the difference between the two sets of data is a factor of nine (the ratio of the molecular weights of water and hydrogen). The mean moisture content for each treatment is listed in Table 2. Equality of the means of each set of three aliquots in Table 1 was tested to eliminate nonrepresentative titanium samples. The results of an F-test [1] for comparison of the equality of sample means for each set of aliquots are given in Table 3. The experimental F-value is the ratio of the variance of the among-aliquot means and the variance of the within-aliquot observations. Since there are three aliquots and five observations for each aliquot, there are 2 and 12 degrees of freedom for each treatment. The theoretical F-value for 2 and 12 degrees of freedom at the $5 \%$ significance level is 3.8853 [2]. As evident from Table 3 only the aliquots of treatment $V$ differ in the means of their observations. The conclusion reached in this statistical evaluation is that aliquots within treatments I, II, III, and IV do not differ significantly at the $5 \%$ level. The level of significance [3] is the probability of committing a type I error which is the rejection of a hypothesis that is true. The hypothesis in evaluating the aliquots of each treatment is that the means of the observations of the three aliquots for each treatment are equal. Thus there is a 0.05 chance that the observations of the three aliquots of treatment $V$ belong to the same population. This chance is even more unlikely because at the $0.5 \%$ significance level for 2 and 12 degrees of freedom, $F=8.5096$, and the aliquots of treatment $V$ still show a difference in their means.

To locate the nonrepresentative aliquot in treatment $V$, a t-test [4] was applied to their observations. The results in Table 4 indicate that the mean of the observations of aliquot $S_{1}$ of treatment $V$ differs significantly from the other two at the $5 \%$ significance level for 8 degrees of freedom $(t-1.860[5])$. There is still a significant difference at the $0.5 \%$ level ( $t=3.355$ ). The results of this aliquot were dropped in the final comparison between the means of the five treatments.

To establish that a difference exists among the means of the observations of the five treatments, an F-test was applied to tlie entire set of data. Table 5 lists the pertinent statistics. It is highly obvious that a significant difference exists in the treatments.

The final statistical evaluation (Table 6) compares all the treatments, one pair at a time, to establish that all treatments are significantly different from one another. The degrees of freedom for those pairs containing treatment $V$ are five less than the others because the five observations of 
Table 1

NMR RESULTS FOR TREATMENTS OF TITANIUM METAL POWDER SAMPLE QC 1779

Weight Percent Water

I

\begin{tabular}{|c|c|c|c|}
\hline \multirow{2}{*}{$\frac{\text { Treatment }}{\text { Aliquot }}$} & \multicolumn{3}{|c|}{$\begin{array}{l}\text { Air-Dried } \\
\text { Over Weekend }\end{array}$} \\
\hline & $\mathrm{S}_{1}$ & $\mathrm{~S}_{2}$ & $\mathrm{~S}_{3}$ \\
\hline $\begin{array}{l}\text { Date } \\
12-30-76\end{array}$ & 1.17 & 1.17 & 1.17 \\
\hline $11-30-76$ & 1.16 & 1.10 & 1.17 \\
\hline $12-01-76$ & 1.14 & 1.20 & 1.14 \\
\hline $12-01-76$ & 1.17 & 1.18 & 1.17 \\
\hline $1-202-76$ & 1.20 & 1.16 & 1.06 \\
\hline $12-03-76$ & - & - & - \\
\hline
\end{tabular}

II

High-Vac Furnace $\frac{10^{-5} \text { torr, } 195^{\circ} \mathrm{C}, 88 \mathrm{Hr}}{\underline{\mathrm{S}_{1}}+\mathrm{S}_{2} \mathrm{~S}_{3}}$

$\begin{array}{lll}0.54 & 0.49 & 0.49\end{array}$

$\begin{array}{lll}0.50 & 0.50 \quad 0.50\end{array}$

$\begin{array}{lll}0.48 & 0.47 & 0.46\end{array}$

$\begin{array}{lll}0.41 & 0.37 & 0.38\end{array}$

$\begin{array}{lll}0.45 & 0.42 & 0.47\end{array}$ $50 \mu \mathrm{m}, 105^{\circ} \mathrm{C}, 24 \mathrm{Hr}$

$\begin{array}{cccc}11-30-76 & 0.127 & 0.127 & 0.127 \\ 11-30-76 & 0.129 & 0.122 & 0.127 \\ 12-01-76 & 0.127 & 0.133 & 0.127 \\ 12-01-76 & 0.130 & 0.131 & 0.130 \\ 12-02-76 & 0.133 & 0.129 & 0.129 \\ 12-03-76 & - & - & -\end{array}$

$\underline{\text { III }}$

Low-Vac Furnace

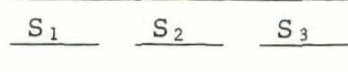

$\begin{array}{lll}0.65 & 0.69 & 0.64\end{array}$

$\begin{array}{lll}0.78 & 0.78 & 0.70\end{array}$

$\begin{array}{lll}0.79 & 0.79 & 0.74\end{array}$

$\begin{array}{lll}0.80 & 0.78 \quad 0.75\end{array}$

$\begin{array}{lll}0.77 & 0.77 & 0.74\end{array}$

Weight Percent Hydrogen

IV

Treatment III Plus $1 \mathrm{Hr}$ Air Exposure

$\underline{\mathrm{S}_{1}} \stackrel{\mathrm{S}_{2}}{\mathrm{~S}_{3}}$

$\begin{array}{lll}0.83 & 0.80 \quad 0.85\end{array}$

$\begin{array}{lll}0.99 & 0.89 & 0.93\end{array}$

$\begin{array}{lll}0.95 & 0.86 & 0.86\end{array}$

$\begin{array}{lll}0.90 & 0.86 & 0.86\end{array}$

$-$

$\begin{array}{lll}0.93 & 0.93 & 0.91\end{array}$

$\begin{array}{llllll}0.060 & 0.054 & 0.054 & 0.072 & 0.077 & 0.071 \\ 0.056 & 0.056 & 0.056 & 0.087 & 0.087 & 0.078 \\ 0.053 & 0.052 & 0.051 & 0.088 & 0.088 & 0.082 \\ 0.045 & 0.041 & 0.042 & 0.089 & 0.087 & 0.083 \\ 0.050 & 0.047 & 0.052 & 0.086 & 0.086 & 0.082\end{array}$

$\begin{array}{lll}0.092 & 0.089 & 0.094\end{array}$

$0.110 \quad 0.099 \quad 0.103$

$\begin{array}{lll}0.106 & 0.096 & 0.095\end{array}$

$\begin{array}{lll}0.100 & 0.096 & 0.095\end{array}$

$0.103 \quad 0.103 \quad 0.101$
Treatment $\frac{V}{t}$ II Plus

$45 \mathrm{Hr} \mathrm{100 \%} \mathrm{Humidity}$

\begin{tabular}{l}
$45 \mathrm{Hr} 100 \%$ Humidity \\
in Sealed Dessicator \\
\hline
\end{tabular}

$\mathrm{S}_{1} \quad \mathrm{~S}_{2} \quad \mathrm{~S}_{3}$

$2.32 \quad 1.74 \quad 1.74$

$\begin{array}{lll}1.90 & 1.50 \quad 1.48\end{array}$

$\begin{array}{lll}1.88 & 1.49 & 1.42\end{array}$

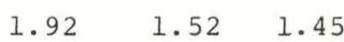

$\begin{array}{lll}1.99 & 1.57 \quad 1.57\end{array}$

$\begin{array}{llll}0.258 & 0.193 & 0.193\end{array}$

$\begin{array}{lll}0.211 & 0.167 & 0.164\end{array}$

$\begin{array}{lll}0.213 & 0.169 & 0.161\end{array}$

$\begin{array}{lll}0.213 & 0.169 & 0.161\end{array}$

$\begin{array}{lll}0.221 & 0.174 & 0.074\end{array}$ 
Table 2

AVERAGE MOISTURE CONTENT OF VARIOUS TREATMENTS OF

TITANIUM METAL POWDER SAMPLE QC 1779

\begin{tabular}{|c|c|c|}
\hline $\begin{array}{l}\text { Treat- } \\
\text { ment }\end{array}$ & Description & $\begin{array}{l}\text { Mean } \\
\text { Moisture } \\
\text { Content } \\
(\text { wt } \%) \\
\end{array}$ \\
\hline I & $\begin{array}{l}\text { Air-dried } 72 \mathrm{hr} \\
\text { Loaded in air }\end{array}$ & $1.16_{4}$ \\
\hline II & $\begin{array}{l}\text { High-vac furnace } \\
10^{-5} \text { torr, } 195^{\circ} \mathrm{C}, \\
88 \mathrm{hr} \\
\text { Loaded in vacuum }\end{array}$ & 0.462 \\
\hline III & $\begin{array}{l}\text { Low-vac furnace } \\
50 \mu \mathrm{m}, 105^{\circ} \mathrm{C}, \\
24 \mathrm{hr} \\
\text { Loaded in vacuum }\end{array}$ & 0.745 \\
\hline IV & $\begin{array}{l}\text { Low-vac furnace } \\
\text { Exposed to air } 1 \mathrm{hr} \\
\text { Loaded in air }\end{array}$ & 0.890 \\
\hline V & $\begin{array}{l}\text { Low-vac furnace } \\
\text { Exposed to } 100 \% \\
\text { humidity } 45 \mathrm{hr} \\
\text { Loaded in air }\end{array}$ & 1.548 \\
\hline
\end{tabular}

Table 4

T-TEST FOR COMPARISON OF OBSERVATIONS FOR ALIQUOTS OF TREATMENT V

Aliquot Comparison

$\mathrm{S}_{1}$ and $\mathrm{S}_{2}$

Experimental $t$

4.671

$\mathrm{S}_{1}$ and $\mathrm{S}_{3}$

4.700

$\mathrm{S}_{2}$ and $\mathrm{S}_{3}$

0.433

Significance Level : $5 \%$

Degrees of Frecdom : 8

Critical Region : $t>1.860$
Table 3

F-TEST ANALYSIS OF VARIANCE FOR TESTING EQUALITY OF ALIQUOT SAMPLES

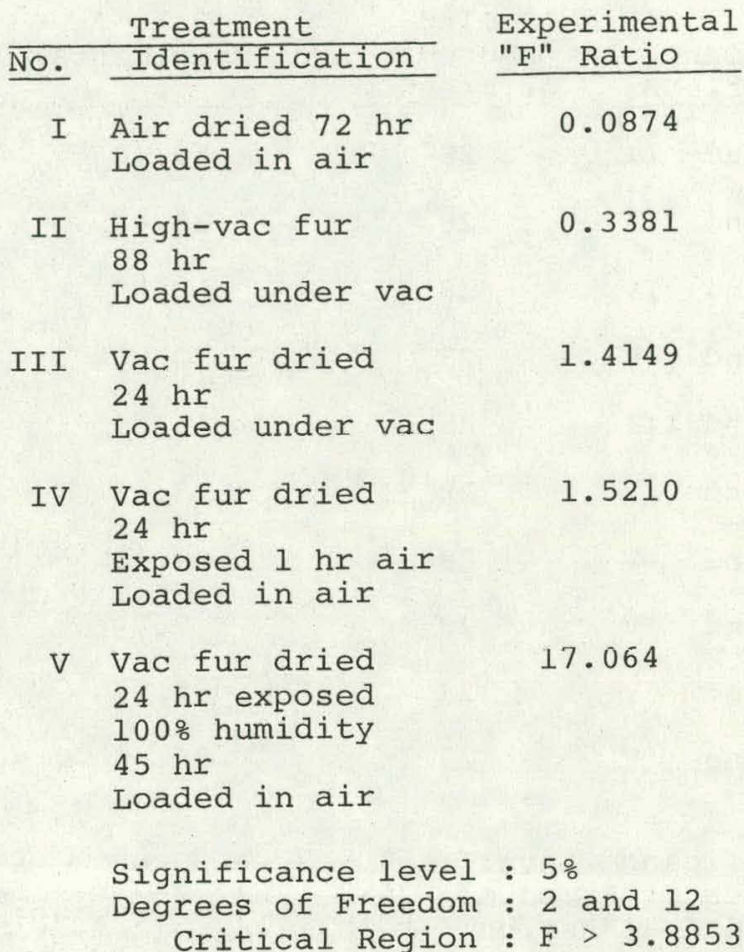

Table 5

F-TFET ANATYYSIS OF VARIANCE FOR EQUALITY OF TREATMENT OBSERVATIONS

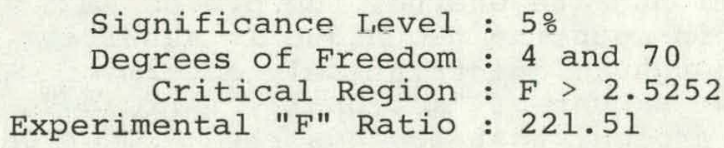


Table 6

t-TEST FOR COMPARISON OF TREATMENT OBSERVATIONS

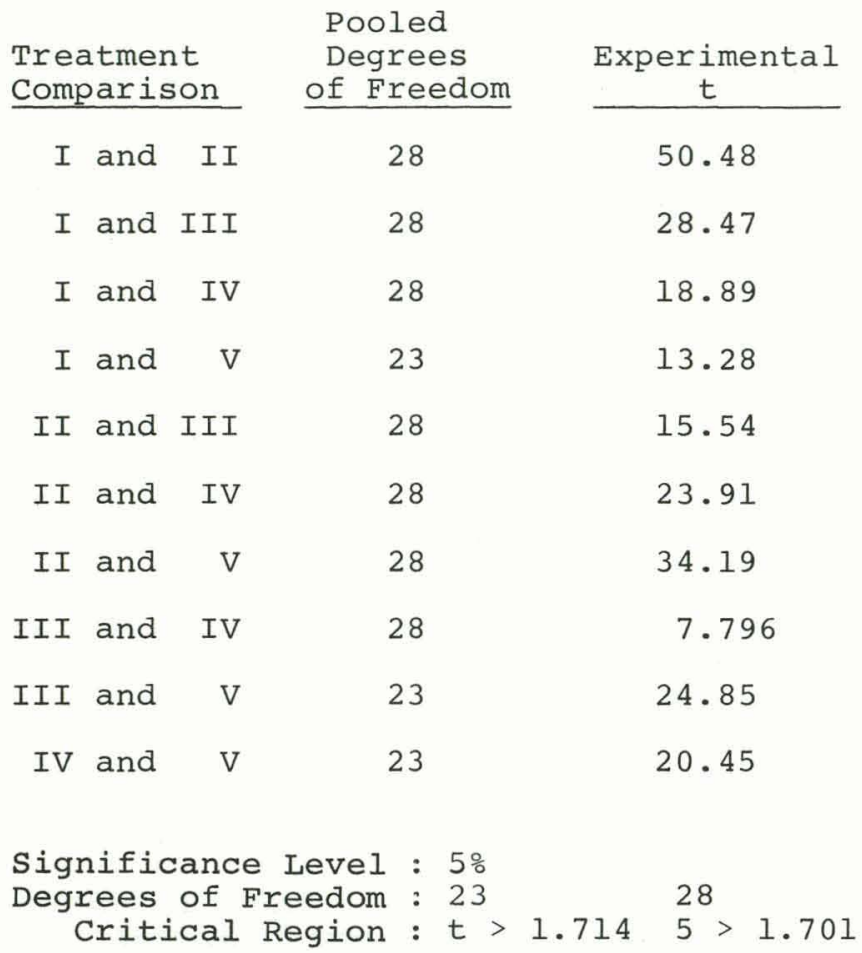

aliquot $\mathrm{S}_{1}$ were dropped. The pooled degrees of freedom is the sum of the degrees of freedom of the treatments being compared.

\section{RESULTS AND DISCUSSION}

The purpose for these NMR experiments on high-surface-area titanium metal powder was the following:

1. Demonstrate whether the proton NMR spin-counting technique is sensitive enough to quantitatively determine the amount of "motionally narrowed" hydrogen, that is, adsorbed $\mathrm{H}_{2} \mathrm{O}$ or $\mathrm{OH}$, in high-surface-area titanium metal powder.

2. Estimate the effectiveness of "normal" drying procedures, that is, $24 \mathrm{hr}$ at $105^{\circ} \mathrm{C}$ in "vacuum" of approximately 50 torr, used in pyrotechnics processing.

3. Determine the effect of "normal" atmospheric exposure on "hydrogen $/ \mathrm{H}_{2} \mathrm{O}$ " content of the titanium powder.
4. Determine maximum amount of moisture removable by drying under reasonable production conditions.

The pulsed NMR investigation provided positive results for all the goals sought in this study. The spin-counting technique is sensitive enough to detect "adsorbed" moisture. Under the conditions of this experiment the sensitivity of detection of $\mathrm{H}_{2} \mathrm{O}$ is estimated to be $0.03 \mathrm{wt} \%$ from the results of Figure 2. The limit of detection is defined here as a signal having a 2:1 signal-to-noise ratio. This signal would be distinguishable from noise and would be observable on the oscilloscope screen. Greater sensitivity can be achieved simply by increasing the number of scans. The signal-to-noise ratio increases in proportion to the square root of the number of scans. Normal drying (treatment III) did prove effective in drying titanium metal powder sample QC 1779 ( 0.42 wt $\% \mathrm{H}_{2} \mathrm{O}$ lost, the difference between treatments I and III). Normal atmospheric exposure (treatment IV) of sample QC 1779 does result in adsorption of moisture (0.15 wt $\%$ increase in a l-hr exposure the difference between treatments III and IV). Reasonable drying conditions (treatment III) desorbs $60 \%$ of the removal moisture (the ratio of the differences between treatments I and III and treatments I and II).

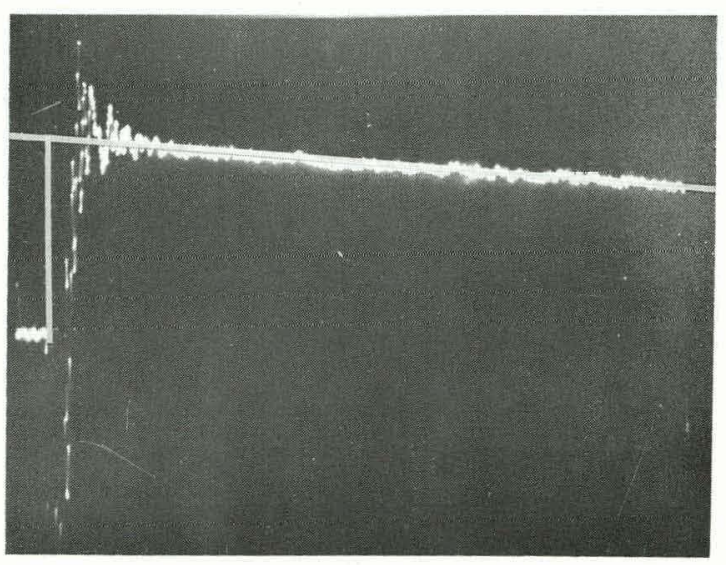

FIGURE 2 - Proton pulsed NMR free induction decay signal to illustrate the sensitivity of detection of hydrogen in a $0.6 \mathrm{~g}$ sample of deuterium oxide containing 1.25 $x 10^{20}$ hydrogen nuclei $\left(<0.2\right.$ wt $\left.\% \mathrm{H}_{2} \mathrm{O}\right)$.

The interpretation of the NMR results can be seen more clearly if the treatments are divided into two groups. One group consisting of treatments I, II, and III provides information on the most effective 
drying method (treatment II). The other group consisting of treatments II, III, and $V$ establishes that moisture is readily adsorbed by titanium metal powder sample QC 1779 .

The titanium powder used in this investigation is essentially a moist sample taken from a larger batch of material shipped to Mound Laboratory from Sandia, Albuquerque, in a very wet condition. The moist sample was kept in a closed black container for approximately five months prior to the weekend exposure to air (treatment I). During the five-month storage period the material gradually lost moisture and appeared nearly dry (in a caked condition) at the start of the experimental treatments.

In treatment I the moisture in the sample was allowed to equilibrate with the moisture in the atmosphere (humidity unknown, but much less than 100\%) at room temperature over the weekend $(72 \mathrm{hr})$. In treatments II and III progressively more moisture was removed from the samples because of a combination of decreased pressure ( $5.0 \times 10^{-2}$ torr to $10^{-5}$ torr), increased temperature $\left(105\right.$ to $\left.195^{\circ} \mathrm{C}\right)$, and increased time of treatment $(24$ to $88 \mathrm{hr})$.

No experiments were designed to determine the effect of temperature, pressure, and time in reducing the moisture content of the samples. The design of this experiment would require eight treatments ( $2 \mathrm{x}$ $2 \times 2$ factorial experiment) of a sample in. a high vacuum furnace. The factorial experiment would have to be repeated at least twice to obtain the experimental error.

The results of treatments III, IV, and $V$ indicate that uptake of moisture by titanium metal powder sample QC 1779 depends on relative humidity. Again no experiments were designed to determine the combined effect of temperature, relative humidity, and time on the uptake of moisture by these samples. This design would also bc a $2 \times 2 \times 2$ factorial experiment.

The apparent residual moisture found in the samples of treatment II indicates that some water is chemically bound in the titanium or that hydrogen exists in some other form, such as $\mathrm{T} i(\mathrm{OH})_{\mathrm{x}}$. All physically adsorbed water should have been expelled under the extreme conditions of treatment II. Hydrogen atoms in the hydride phase of TiHo.15 (QC 1779) are "rigid lattice" protons that do not contribute to the slow decaying signal which is assumed to be adsorbed water or other form of $\mathrm{OH}$. The results of this study and the CEC (Consolidated Electrodynamics Corp.) moisture data for the $\mathrm{TiH}_{0.1} 5$ material support the validity of this assumption. The results of a chemical analysis of sample QC 1779 are given in Table 7 . The sample submitted for this chemical analysis was heated for $24 \mathrm{hr}$ in a vacuum furnace at $105^{\circ} \mathrm{C}$ and $50 \mu \mathrm{m}$ pressure. After cooling to room temperature and exposed to air, the sample was stored in a sealed black velostat conductive container for an undetermined time before the moisture analysis. This sample is comparable to our treatment number IV Sample, which approximates the normal pyrotechnics process treatment desćribed above. Oxygen was obtained from neutron activation analysis, hydrogen from decomposition of the material at $1000^{\circ} \mathrm{C}$, and moisture from a Consolidated Electrodynamics Corporation moisture analyzer. Assuming that only water is driven from the samples during mild heat treatment $\left(100-200^{\circ} \mathrm{C}\right)$, the difference $\left(0.428\right.$ wt $\left.8 \mathrm{H}_{2} \mathrm{O}\right)$ in water content between treatments II and IV agrees very closely with the CEC analysis 10.42 wt o $\mathrm{H}_{2} \mathrm{O}$ ). The NMR technique for determining hydrogen includes all forms of mobile hydrogen, resulting in a value larger than the CEC analysis. The sample of treatment II serves as a background sample which corrects for all hydrogen not removed as water. The chemical analysis and the statistical evaluation strongly indicate that the NMR method does give a representative measure of the moisture gained or lost during the various treatments. This was the main purpose of this investigation.

\section{REFERENCES}

1. Jerome C. R. Li, "Stastical Inference $I$," Edwards Brothers, Inc., Ann Arbor, Michigan, Chapter 12, 1969.

2. Ibid., table 7a, p. 603 .

3. Ibid., p. 54 .

4. Ibid., Chapter 10.

5. Ibid., table 6, p. 602 . 
Table 7

DATA SUMMARY

Sample QC \# 1779 ET

Elemental Analysis

oxygen

Hydrogen

Nitrogen

Carbon

sulfur (wt 8)

$5.19 \pm 0.11$

0.31

$0.4 \pm 0.2$

0.10

0.016

Trace Impurities - Emission Spectroscopy (wt \&)

$\begin{array}{lllr}\text { Silicon } & 0.15 & \text { Aluminum } & 0.02 \\ \text { Iron } & 0.1 & \text { Zinc } & 0.008 \\ \text { Zirconium } & 0.08 & \text { Copper } & 0.007 \\ \text { Phosphorus } & 0.06 & \text { Boron } & \leq 0.005 \\ \text { Magnesium } & \geq 0.3 & \text { Chromium } & \leq 0.005\end{array}$

Assay (wt $\%$ )

$94.488 \mathrm{Ti}$

Moisture (wt 8 )

$0.428 \mathrm{H}_{2} \mathrm{O}$

Sodium

$25 \mathrm{ppm}$

Particle Size-Coulter Counter ( $\mu \mathrm{m} / 50 \%) 1.1$

Apparent Stoichiometry

$\mathrm{TiH}_{0.1} 5$ 
DISTRIBUTION

\section{EXTERNAL}

$\mathrm{UC}-4$

J. A. Chacon, DAO

R. K. Flitcraft, MRC

W. E. Moddeman, U. D. Res. Inst.

C. P. Sutter/R. N. Diebel, ARHCO

\section{SIA}

D. H. Anderson

N. E. Brown

E. A. Kjeldgaard

M. L. Lieverman

T. M. Massis

R. K. Quinn

B. R. Steele

R. E. Whan

INTERNAL
A. Attalla
R. C. Bowman
D. R. Bohl
J. R. Brinkman
W. T. Cave
B. D. Craft
R. J . DeSando
C. W. Huntingtón
L. V. Jones
C. M. Love
$\mathrm{J}$. R. McClain
R. J. Salerno
D. E. Sellers
R. E. Vallee
R. L. Yauger Library (15)
Publications 